UNIO - EU Law Journal. Vol. 7, No. 1, July 2021, pp 50-66.

®2021 Centre of Studies in European Union Law

School of Law - University of Minho

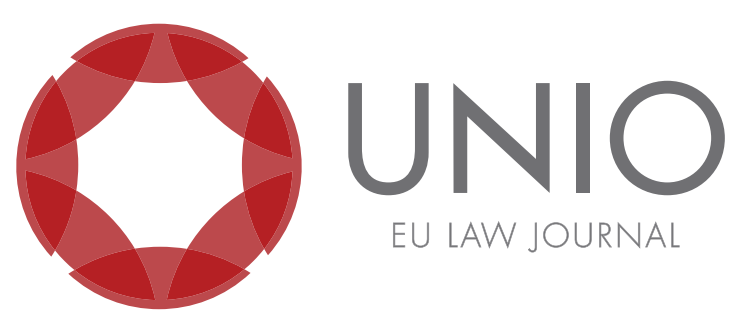

\title{
Personal data protection and access to information: interfaces of Civil Society role in Brazilian legislative process
}

\author{
Ana Claudia Farranha Santana* \\ Murilo Borsio Bataglia** \\ Amanda Nunes Lopes Espiñeira Lemos***
}

ABSTR ACT: The relationship between access to information and personal data protection leads to the relativization of transparency under the argument of a false tradeoff between these two concepts. Based on that, this study's objective is to understand the role of Civil Society movements in maintaining the rights of access to information and personal data protection. This research made a qualitative analysis, with a documentary survey and bibliographic review of the main categories presented in the Executive-Legislative relationship and in the theme of advocacy. We observe the role of Civil Society lobby groups in the Brazilian Access to Information Law legislative process, between 2003 and 2011, and the Brazilian Data Protection Act, between 2012 and 2018, perceive the change of these groups with the foundation of Rights in Network Coalition, in 2016. As a result, the active participation of Civil Society in public hearings has intensified increasingly since 2018, especifically on the LGPD, while LAI bad participation of Civil Society in the body's scope institutionalized.

KEYWORDS: Legislative process - access to information - data protection - Rights in Network Coalition - participatory democracy.

\footnotetext{
${ }^{*} \mathrm{PhD}$ in Social Sciences at State University of Campinas (UNICAMP). Professor of Law at University of Brasilia (Faculty of Law/UnB). Coordinator of Public Policy Watchdog Research Group (GEOPP/UnB).

${ }^{* *} \mathrm{PhD}$ student and Master's in Law at University of Brasília (UnB). Lecturer at University of Brasilia (CEAM/IPOL/UnB). Member of Public Policy Watchdog Research Group (GEOPP/UnB).

${ }^{* * *} \mathrm{PhD}$ student and Master's in Law at University of Brasília (UnB). Scholarship holder from Fiocruz Brasília. Researcher at Public Policy and Internet Laboratory (LAPIN). Member of Studies in Telecommunications Law Research Group (GETEL).
} 


\section{Introduction}

The right to information is understood as being oxygen for democracy. ${ }^{1}$ Such a right is fundamental for the effectiveness of this regime since it enables social insertion by enabling the citizen to make choices and to participate politically. It is a prerequisite for the exercise of citizen participation. In global terms, the availability and increasing consumption of information, the influence of means of communication and new technologies enhance this informational reach in several areas.

This debate, in the Brazilian context, presents constitutional foundations that demonstrate the treatment of the right to information as a fundamental right. In this context, there is the Access to Information Law (Law no. 15,527 of 2011 - "LAI" in Portuguese), which was the result of a wide discussion in the Council for Public Transparency and Combating Corruption (CTPCC, in Portuguese), a deliberative body of the CGU composed of representatives of the State and the Civil Society, especially NGOs interested in the topic.

Despite being a 2011 law, this topic has returned to the agenda of discussions in recent months in face of attempts to change it, at the beginning of the new government and now in times of a pandemic. This theme also promotes a reflection with recent changes or updates in the General Law for the Protection of Personal Data ("LGPD" in Portuguese), including delays to entry into force. Given these elements, it seeks to interlace the interfaces between transparency and privacy, questioning the false tradeoff that exists between these two concepts. ${ }^{2}$ The creation of the LGPD was accompanied by a Civil Society advocacy movement called the Rights in Network Coalition (Coalizão Direitos na Rede), which works in the Brazilian Congress. In this sense, the question arises: what was the role of Civil Society in the advocacy of legislative proposals on Access to Information and Protection of Personal Data?

This article aims to understand the role of Civil Society movements in maintaining the right of access to information ${ }^{3}$ and transparency as well as in preserving the right to privacy and the protection of personal data. For this purpose, these following specific objectives are intended (a) to analyse the performance of Civil Society groups in the following legislative processes: (a.1) the Access to Information Law (Law no. 12.527 / 2011) and (a. 2) of the General Data Protection Law (Law no. 13.709 / 2018), with the amendment of MP no. 869/2018 on the Data Protection Authority; and (b) to evaluate the changes in the performance of these groups with the formation of the group Rights in Network Coalition.

\footnotetext{
${ }^{1}$ Tobby Mendel, Liberdade de informação: um estudo de direito comparado (Brasília: UNESCO, 2009).

${ }^{2}$ D.J. Solove, Nothing to hide: the false tradeoff between privacy and security (Yale: University Press New Haven \& London, 2001).

${ }^{3}$ Although it is not the objective of the work to reflect on various aspects of the right of access to information, it is important to make brief comments. Thus, such a right is seen as a fundamental right, foreseen both in International Treaties (art. 19, Universal Declaration of Human Rights, for example), and in the Brazilian Constitution, as will be explained in the text. Furthermore, it is seen as oxygen for democracy, given its importance related to the individual being informed, informing and being informed (Murilo Borsio Bataglia and Ana Claudia Farranha, "Corrupção, transparência e CGU: analisando o contexto para a implementação do direito de acesso à informação", NAU - A Revista Eletrônica da Residência Social, v. 10 (2019): 23-50, https:/ / portalseer.ufba.br/index.php/nausocial/article/ view/33923/19659; Maria Eduarda Cintra, "Lei de acesso à informação no Brasil: sua implementação e seus desafios" (Dissertation, University of Brasilia, 2016); Tobby Mendel, Liberdade de informação: um estudo de direito comparado (Brasília: UNESCO, 2009).
} 
Methodologically, a qualitative research will be carried out with documentary analysis, presentation of bibliographic references of the main categories identified in the Executive-Legislative relationship and the theme of advocacy. The verification of this analysis will occur through the process in the Chamber of Deputies, and the participation of Civil Society in the debates, in councils (meeting minutes of such councils considered as data sources, as the case of the CTPCC - Council for Transparency and Prevention in Combating Corruption), as well as the notes published by the Rights Coalition on the Network on its website.

This work is organised into two parts. The first is about the lobby ${ }^{4}$ as an essential element for understanding participation processes, which originate from a liberal and plural theoretical perspective in decision making in the legislative process. In the second, subdivided into three subparts, the role of Civil Society groups in the legislative processes of the Access to Information Law and the General Data Protection Law is mapped, as well as the changes that have occurred in this performance, from the Network Rights Coalition.

\section{Lobby in the legislative process as assumption of plural democracy}

Lobby is often used as a synonym for the term advocacy. Some authors, however, differentiate both and conceptualise "advocacy" as a defense focused on a specific issue. "Due to the strong negative stigma surrounding the practice of lobbying, many of them choose to identify themselves as government relations professionals; institutional representation; political consultancy, analysis, and advice; corporate advocacy, among other denominations". ${ }^{5}$

"In the academic literature, the concept of lobbying has a more restricted meaning, referring to the defense of interests before members of the public power who can make political decisions". 6 There are three directions of action of these interest groups: (1) seeking to influence the decision-making process; (2) trying to open channels of communication with the Executive Branch; and (3) obtain information relevant to the strategic planning of its sectors of interest. ${ }^{7}$

One of the leading roles of a lobbyist is "to collaborate with the difficult task of decision-makers by providing them with information about the items on the agenda" , since the legislative process constantly involves complex issues, technical and specific, with which parliamentarians are unfamiliar. ${ }^{9}$

The role of Civil Society in a group, composed of several other organised groups that lobby, raises the debate on the question of these groups' organisational

\footnotetext{
${ }^{4}$ L. Graziano, “O lobby e o interesse público”, Revista Brasileira de Ciências Sociais, v. 12, no. 35 (1997), doi: https://dx.doi.org/10.1590/S0102-69091997000300009.

${ }^{5}$ W. Mancuso and A. C. Gozetto, "Lobby: instrumento democrático de representação de interesses?”, Organicom, v. 8, no. 14 (2011): 121.

${ }^{6}$ Mancuso and Gozetto, "Lobby: instrumento democrático de representação de interesses?”, 120.

${ }^{7}$ M. L. Santos, Representação de interesses na arena legislativa: os grupos de pressão na Câmara dos Deputados (1983-2012) (IPEA: Brasília, 2014), 7-39, http://www.ipea.gov.br/portal/images/stories/PDFs/ TDs/td_1975.pdf.

${ }^{8}$ Mancuso and Gozetto, “Lobby: instrumento democrático de representação de interesses?”, 123.

${ }^{9}$ E. Diniz and R. Boschi, "O Legislativo como arena de interesses organizados: a atuação dos lobbies empresariais”, Locus revista histórica, v. 5, no. 1 (1999):7-32. E. Diniz and R. Boschi, Empresários, interesses e mercado. Dilemas do desenvolvimento no Brasil (Belo Horizonte: Editora UFMG/Rio de Janeiro: IUPERJ, 2004).
} 
capacity. Mancuso ${ }^{10}$ points to the imbalance of forces generated mainly by capital when "small groups (for example, entrepreneurs in oligopolist economic sectors) bave more incredible facility than large groups (for example, consumers in a competitive market) or taxpayers) to solve collective action problems and create lobbies in search of benefits for its members". ${ }^{11}$

To address this imbalance, two alternatives are pointed out: (1) the action of the public power to equalise these disparities; and (2) the role of political entrepreneurs who assist in organising the defense of interests with difficulty in collective action. ${ }^{12}$ An example of this second alternative is IDEC - Brazilian Institute for Consumer Protection, which is part of the Rights in Network Coalition. ${ }^{13}$ In this case, IDEC works by providing information to the Coalition, which works to help small organisations and join forces of concurrent guidelines that deal with the defense of rights in the network.

There is a crisis of representativeness and liberal democracy globally, and Brazil is not outside this movement. However, there is a need to maintain a democratic bias reframing these concepts and values. New technologies must be seen as an essential instrument, to rejuvenate policies and connect urban and virtual space. ${ }^{14}$ Castells complements this idea by adding mistrust in institutions that delegitimise political representation as one of the elements of this crisis of liberal-pluralist democracy. The rupture, therefore, "is a gradual collapse of a political model of representation and governance". ${ }^{15}$

The Civil Society groups' acting process in Congress falls within the context of redefinition of the participation in the construction of laws and decision making. In this sense, Civil Society fits into this scenario as a catalyst for strengthening democracy and understanding its role and participation in the new era of Communication and Information Technologies seems to be essential for the agenda of the Brazilian Legislature. In the next topic, the role of Civil Society groups in the LAI and LGPD process is analysed. ${ }^{16}$

\section{Civil Society groups acting on the legislative process of LAI and LGPD: changes through the Rights in Network Coalition}

The purpose of this section is to carry out an analysis of the participation of Civil Society, whether in groups or in NGOs, or individually, in the drafting or legislative construction of the rights of access to information and protection of personal data. Two subsections express this procedure, with their respective findings and methodologies.

\footnotetext{
${ }^{10}$ Mancuso and Gozetto, "Lobby: instrumento democrático de representação de interesses?”, 124.

${ }^{11}$ Mancuso and Gozetto, "Lobby: instrumento democrático de representação de interesses?”, 120.

${ }^{12}$ Mancuso and Gozetto, “Lobby: instrumento democrático de representação de interesses?”, 124.

13 "The Rights in the Network Coalition is an independent network of civil society organizations, activists and academics in defense of the free and open Internet in Brazil. Formed in July 2016, it seeks to contribute to raising awareness about the right to Internet access, privacy and freedom of expression in a broad way. The collective works on different fronts through its organizations, in a horizontal and collaborative way". Direitos na Rede, “A coalizão", 2020, https:/ / direitosnarede.org.br/\#section-0.

${ }^{14}$ S. Levitsky and D. Ziblatt, Como as democracias morrem (Rio de Janeiro: Zahar, 2018).

${ }^{15}$ M. Castells, Ruptura: a crise da democracia liberal (Rio de Janeiro: Zahar, 2018), 8.

${ }^{16}$ Suely Araújo and Rafael Silveira, "Representações políticas alternativas no Congresso Nacional: uma proposta conceitual para compreender as frentes parlamentares”, Revista Direito Público, v. 16, no. 88 (2019), https://www.portaldeperiodicos.idp.edu.br/direitopublico/article/view/3308.
} 


\subsection{Legislative process of LAI: before Rights in Network Coalition}

Once the theme of the lobby is contextualised, this subsection verifies, in practice, how society participated in the processing of the bill regarding the right of access to information - which resulted in the enactment of the LAI (Law no. 12.527 on November 18, 2011). The question is: to what extent did it happen and how was social participation in the process of LAI?

To do this, methodologically, it uses the minutes (published) of the meetings of the Council on Transparency and Public and Combat against Corruption (CTPCCCGU), a deliberative body of the Office of the Comptroller General of the Union (CGU). It also uses the search tool on the Chamber of Deputies website, as a source of data, to verify the process of the bill $\left(\mathrm{PL}^{17} 219 / 2003^{18}\right)$ and possible participatory interventions by society along this path. In the same way it is done on the Senate website, from the moment that this institution received the bill of law of the Chamber of Deputies (PLC no. 41/2010). In this sense, it is intended to observe the holding of public hearings during this process, and to answer the research questions that arise: i) Within the scope of the CTPCC / CGU, was there participation by society? Which entities or institutions acted as advisers? Do they represent any sector of the population? and; ii) In the scope of the national Congress: ii.a) were there public hearings? ii.b) If so, which entities or institutions participated? Finally, the following question is addressed: how did this participation take place?

In addition to these described materials and methodology, such research is reinforced from the literature of recent works on the theme ${ }^{19}$. Thus, once this path and methodological model has been pointed out, it proceeds to the execution of these procedures, opting for the descriptive and exploratory character, following the historical patterns of the facts.

According to the Chamber of Deputies' website on which the project is being processed, on February 26, 2003, deputy Reginaldo Lopes proposed this regulation of the aforementioned constitutional provision. From this proposal, the legislative procedure was followed, going through the Labor, Administration and Public Service (CTASP), Constitution and Justice and Citizenship (CCJ) commissions until reaching the Board of Directors on May 17, 2007, to which PL 1019/2007 was joined.

The process, in turn, continued only in 2009, with the request to join number $4807 / 2009$ of the Deputy Reginaldo Lopes, to Project number 5228/2009, authored by the Executive Branch. PL 1924/2007 was also joined.

At this moment, it is important to highlight, before continuing the description of this legislative path, how PL 5228/2009 was created, coming from the Federal

\footnotetext{
${ }^{17}$ Project of Law (Projeto de Lei, in Portuguese language).

${ }^{18}$ Brasil, Câmara dos Deputados, PL219/2003, Regulamenta o inciso XXXIII do art. 5. a Constituição Federal, dispondo sobre prestação de informações detidas pelos órgãos da Administração Pública, 26/02/2003, https://www.camara.leg.br/proposicoesWeb/fichadetramitacao?idProposicao=105237; Brasil, Câmara dos Deputados, Parecer do relator ao PL219/2003, https://www.camara.leg.br/ proposicoesWeb/prop_mostrarintegra?codteor=736307\&filename=Tramitacao-PL+219/2003.

${ }^{19}$ Murilo Borsio Bataglia, "Acesso à informação e corrupção: investigando o contexto institucional da CGU" (Dissertation, University of Brasilia, 2019). Cintra, "Lei de acesso à informação no Brasil: sua implementação e seus desafios"; Marcio Cunha Filho, "O que sabemos sobre transparência pública? Uma revisão bibliográfica das abordagens normativa, conceitualista e empírica”, Revista da CGU, v. 10 , no. 16 (2018): 878-907, https://ojs.cgu.gov.br/index.php/Revista_da_CGU/article/view/55/pdf_37. Wilson Gomes et al., "Novos desafios para a ideia de transparência pública", VI Congresso da Associação Brasileira de Pesquisadores em Comunicaşão e Política (VI COMPOLITICA) (2015), https://www.e-compos. org.br/e-compos/article/view/1446.
} 
Executive Branch itself. As mentioned at the beginning of this work, despite being jointly authored by institutions and bodies of the Federal Executive Branch (encompassing some ministries through the Interministerial Motives Exhibition EMI no. 00007 CC / MJ / MRE / MD / AGU / SEDH / GSI / SECOM / CGU$\mathrm{PR})$, it was prepared and discussed within the scope of the CGU CTPCC, which brings together several state entities and representatives of society.

Thus, as a source of data to verify the discussion of this project, there are the minutes of this Council for Public Transparency and Fight against Corruption ${ }^{20}$. It is a body that brings together entities representing Civil Society (selecting them through participation in a specific notice) and that makes up the basic structure of the CGU (Article 53, I, Law no. 13.844/2019). ${ }^{21}$ Discussions in this council, in turn, started in 2005, at the fourth meeting $(09 / 20 / 2005),{ }^{22}$ in which the presentation of a preliminary draft prepared by CGU to discuss access to information was on the agenda. As a result, this proposal was accepted by the councilors, forming a working group for the elaboration and studies about this project.

At the fifth meeting (03/23/2006), therefore, the results of the working group meetings on the preliminary project were presented. As suggestions and elements of the debate made among the councilors, the representative of Transparency Brazil (or, in Portuguese, Transparência Brasil), for example, suggested the need for access to an entire database, and suggested the existence of an agency responsible for the resources, to which citizens could turn to in case of failure to obtain the requested information, with scope for the Federal Executive. ${ }^{23}$

At the sixth meeting $(06 / 28 / 2006)$, reports were made on the progress of the work of the group responsible for the preliminary draft of the access to information law, as well as the preliminary draft that was consolidated. ${ }^{24}$

According to the minutes of meeting number 7 (07/26/2007), there were reports on the progress of the bill. It was forwarded to the Civil House, which analysed whether it would be feasible to submit it to public consultation and whether it would be pertinent to join others. Preliminary bills, also submitted to the Civil House, would have likely had thematic similarities.

\footnotetext{
${ }^{20}$ It is an advisory body, which makes up the basic structure of the CGU. And its purpose is "to debate and suggest measures for the improvement and promotion of policies and strategies, within the scope of the federal public administration. In addition, it has the role of planning strategies to fight corruption and impunity". Brasil, CTPCC, Seleção CTPCC, (2019), https://www.cgu.gov.br/ assuntos/transparencia-publica/conselho-da-transparencia/selecao-conselho-da-transparencia.

${ }^{21}$ Brasil, Lei 13.844, de 18 de junho de 2019, estabelece a organização básica dos órgãos da Presidência da República e dos Ministérios; altera as Leis nos 13.334, de 13 de setembro de 2016, 9.069, de 29 de junho de 1995, 11.457, de 16 de março de 2007, 9.984, de 17 de julho de 2000, 9.433, de 8 de janeiro de 1997, 8.001, de 13 de março de 1990, 11.952, de 25 de junho de 2009, 10.559, de 13 de novembro de 2002, 11.440, de 29 de dezembro de 2006, 9.613, de 3 de março de 1998, 11.473, de 10 de maio de 2007, e 13.346, de 10 de outubro de 2016; e revoga dispositivos das Leis nos 10.233, de 5 de junho de 2001, e 11.284, de 2 de março de 2006, e a Lei n ${ }^{\circ} 13.502$, de $1^{\circ}$ de novembro de 2017, http:/ /www. planalto.gov.br/ccivil_03/_ato2019-2022/2019/Lei/L13844.htm.

${ }^{22}$ Brasil, CTPCC, Ata da 4. ${ }^{a}$ reunião, 2005, https://www.cgu.gov.br/assuntos/transparencia-publica/ conselho-da-transparencia/documentos-de-reunioes/atas/ata-da-4a-reuniao-set-2005.pdf.

${ }^{23}$ Today this appeal body within the Federal Executive is CGU itself, specifically the OGU (Ombudsman-

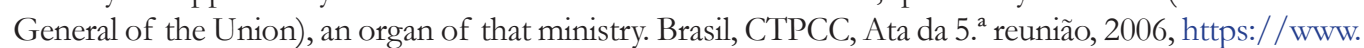
cgu.gov.br/assuntos/transparencia-publica/conselho-da-transparencia/documentos-de-reunioes/atas/ ata-da-5a-reuniao-mar-2006.pdf.

${ }^{24}$ Brasil, CTPCC, Ata da 6. ${ }^{a}$ reunião, 2006, 06-07, https://www.cgu.gov.br/assuntos/transparenciapublica/conselho-da-transparencia/documentos-de-reunioes/atas/ata-da-6a-reuniao-jun-2006.pdf.
} 
The eighth meeting $(08 / 28 / 2007)$ was also intended to inform about the bill that was in the Civil House. It was decided to bring it together with other proposals on the same topic coming from the Ministry of Justice and the Public Ministry. ${ }^{25}$

The tenth meeting (03/25/2009) tried to present the bill on access to information, seeking to outline the final position of the council, before forwarding it to Congress. ${ }^{26}$ At this meeting, several entities from society and State bodies contributed with considerations. Thus, when doing the mapping, there is a report of some of these narratives, linked to expressions present in the analysed project, and their scope:

- Transparency Brazil: when analysing the final project, it considered that it brought improvements in relation to the original. It considered that the project does not extend to the three branches and spheres of government. "The restriction of the PL to the scope of the Federal Executive Branch may constitute a serious error". ${ }^{27}$ It reported that it is at the state and municipal level where the difficulties for access are;

- Representative of the Federal Audit Court: spoke about the need for uniformity regarding the scope of the project;

- ABONG: agreed with the observations regarding the scope of the project. In addition, it warned of the need for an autonomous appeals body/agency if the scope of the project for the three branches is observed. He also highlighted the need for annual publication of a list with elements on classified documents; - Public Ethics Committee of the Presidency of the Republic (CEP): raised questions about the expression "whenever possible", which, in his view, relativises the State's duty;

- ETHOS Institute: also agreed to rethink the scope issue. It cited the recommendation of the Inter-American Commission for information to be released regarding the time of the dictatorship;

- OAB: resumed the observation about avoiding expressions "whenever possible", and "may", asserting the need to define responsibilities;

- CNBB: it also guided the scope of the PL, and it should include an information treatment methodology, "standardizing concepts, in order to enable the knowledge and consequent comparison of the information. It also pointed that, even maintaining the PL coverage only to the Federal Executive Branch there would already be gains"; 28

- Civil House: reported that it started work on December 2006 at the provocation of the CGU. It warned that certain expressions restrict the government's power to extend confidentiality reserves;

- Secretary of the Board: corroborated the affirmation of the Civil House;

- Ministry of Finance: agreed to increase the scope of the project;

- Minister of CGU: accepted contributions from State entities and bodies;

\footnotetext{
${ }^{25}$ Brasil, CTPCC, Ata da 8 reunião, 2007, https://www.cgu.gov.br/assuntos/transparencia-publica/ conselho-da-transparencia/documentos-de-reunioes/atas/ata-da-8a-reuniao-ago-2007.pdf.

${ }^{26}$ Brasil, CTPCC, Ata da $10^{a}$ reunião, 2009, https://www.cgu.gov.br/assuntos/transparencia-publica/ conselho-da-transparencia/documentos-de-reunioes/atas/ata-da-10a-reuniao-mar-2009.pdf.

${ }^{27}$ Brasil, CTPCC, Ata da 10a reunião, 2009, 2, https:/ /www.cgu.gov.br/assuntos/transparencia-publica/ conselho-da-transparencia/documentos-de-reunioes/atas/ata-da-10a-reuniao-mar-2009.pdf.

${ }^{28}$ Brasil, CTPCC, Ata da $10^{a}$ reunião, 2009, 3, https:/ /www.cgu.gov.br/assuntos/transparencia-publica/ conselho-da-transparencia/documentos-de-reunioes/atas/ata-da-10a-reuniao-mar-2009.pdf.
} 
Expressed difficulty in implementing an instance other than the CGU. He clarified some expressions about the responsibility of the Public Administration in researching the requested information. ${ }^{29}$

Therefore, it is possible to perceive, specifically in this meeting number 10, the contributions of both members of the State (TCU, Civil House, CGU, Ministry of Finance, CEP, among other bodies that did so during the meetings), as well as from the organisation itself, and Civil Society, through the entities (ABONG, CNBB, OAB, Transparency Brazil, ETHOS Institute). It is important to note that this participation of Civil Society is still in the locus of the Executive Branch but linked to the elaboration of a bill that would later be sent to Congress.

Thus, with regards to the debates on the elaboration of the project, such were the meetings and respective minutes that discussed the matter until it was forwarded to the National Congress.

Before resuming the historical line of approaching the proceedings in National Congress, some information is necessary. Thus, the questions are resumed: within the scope of the CTPCC / CGU, was there participation by society? Which entities or institutions acted as advisers? Do they represent any sector of the population? Therefore, as a response, it is observed that throughout these meetings described above, there were contributions from several actors, among them, as representatives of actors linked to Civil Society (and not the State), with emphasis on the following members:

Table 1 - Representative Civil Society organizations that made up the CTPCC in discussions on the bill of LAI.

\begin{tabular}{|l|}
\hline \multicolumn{1}{|c|}{ Civil Entities } \\
\hline ABI - Brazilian Press Association \\
\hline ABONG - Brazilian Association of Non-Governmental Organizations \\
\hline CNA / SP - Confederation of Agriculture and Livestock of Brazil \\
\hline CNBB - National Confederation of Bishops of Brazil \\
\hline CNC - National Trade Confederation \\
\hline CNI - National Confederation of Industry \\
\hline CGT - General Confederation of Workers \\
\hline CUT - Single Center of Workers \\
\hline Union Force \\
\hline Ethos Institute - Business and Social Responsibility \\
\hline Representative of the Academic and Scientific Community \\
\hline Representative of Evangelical Churches \\
\hline Transparency Brazil \\
\hline
\end{tabular}

Self-elaboration. Source: Minutes of the CTPCC / CGU Meeting.

The above table illustrates the civilian members of the Council, who at some point during these mentioned meetings were present or listed as members of the

\footnotetext{
${ }^{29}$ Brasil, CTPCC, Ata da 10ª reunião, 2009, https:/ /www.cgu.gov.br/assuntos/transparencia-publica/ conselho-da-transparencia/documentos-de-reunioes/atas/ata-da-10a-reuniao-mar-2009.pdf.
} 
council (present or even justifiably absent). It is an important consultative sphere in which social concerns are translated into contributions for better elaboration of programs, bills of law - as verified, or government policies. Just for the purpose of clarification, in the same way, there were the following State members who also participated in this debate (at the time so named):

Table 2 - State organizations/bodies that made up the CTPCC in discussions on the access to information bill

\begin{tabular}{|l|}
\hline \multicolumn{1}{|c|}{ State Bodies } \\
\hline $\begin{array}{l}\text { CGU (Minister and other representatives of the Federal Secretariat of Internal Control, Secretariat } \\
\text { for Preventing Corruption and Strategic Information, Federal Internal Affairs Department, Legal } \\
\text { Advisory) }\end{array}$ \\
\hline MPOG - Ministry of Planning, Budget, and Management \\
\hline Ministry of Finance \\
\hline AGU - Federal Attorney General \\
\hline MJ - Ministry of Justice \\
\hline CC - Civil House \\
\hline CEP - Public Ethics Committee of the Presidency of the Republic \\
\hline MPF - Federal Public Ministry \\
\hline MRE - Ministry of Foreign Affairs \\
\hline TCU - Federal Court of Accounts \\
\hline
\end{tabular}

Self-elaboration. Source: Minutes of the CTPCC / CGU Meeting.

In addition, as a way of illustrating the course of these CTPCC debates, explained descriptively above, we have the following table (composed of the meeting number, and agenda items):

Table 3 - Summary of the CTPCC meetings that debated a bill on access to information

\begin{tabular}{|l|l|l|l|}
\hline Meeting & Date & Agenda & Members attending the meeting \\
\hline $4^{\text {th }}$ & $09 / 20 / 2005$ & $\begin{array}{l}\text { 5. Presentation of the draft } \\
\text { law prepared by the CGU } \\
\text { on access to information. } \\
\text { 6. Debate on access to } \\
\text { information. }\end{array}$ & $\begin{array}{l}\text { Minister of CGU, Inspector of CGU, } \\
\text { Legal Counsel at CGU, AGU, Internal } \\
\text { Control of Civil House, Internal Control } \\
\text { of Min. Finance, CEP, Regional Attorney } \\
\text { of the Republic, ABI, ABONG, Ethos } \\
\text { Institute, CNA / SP, Transparency Brazil, } \\
\text { MRE, TCU External Control. }\end{array}$ \\
\hline $5^{\text {th }}$ & $03 / 23 / 2006$ & $\begin{array}{l}\text { 5. Presentation of the } \\
\text { result of the meeting of the } \\
\text { Working Group on the draft } \\
\text { law that deals with access to } \\
\text { information. }\end{array}$ & $\begin{array}{l}\text { Minister of CGU, Executive Secretary of } \\
\text { the Council, Secretary for the Prevention } \\
\text { of Corruption and Strategic Information, } \\
\text { Legal Advice of CGU, Internal Control of } \\
\text { MPOG, Internal Control of Civil House, } \\
\text { AGU, Internal Control of Min. Finance, } \\
\text { CEP, Regional Attorney of the Republic, } \\
\text { Representative of Evangelical Churches, } \\
\text { ABONG, Transparency Brazil, External } \\
\text { Control of the TCU. }\end{array}$ \\
\hline
\end{tabular}




\begin{tabular}{|c|c|c|c|}
\hline $6^{\text {th }}$ & $06 / 28 / 2006$ & $\begin{array}{l}\text { 3. Reports on the progress of } \\
\text { the working groups that take } \\
\text { care of the Draft Law on } \\
\text { Access to Information and } \\
\text { the proposal to improve the } \\
\text { control of federal resources } \\
\text { transferred to States and } \\
\text { Municipalities. }\end{array}$ & $\begin{array}{l}\text { Minister of CGU, Executive Secretary } \\
\text { of the Council, Legal Advisory at CGU, } \\
\text { Internal Control of MPOG, Internal } \\
\text { Control of Casa Civil, Internal Control } \\
\text { of Min. Finance, CEP, ABONG, } \\
\text { Transparency Brazil, MJ, CNBB Ethos } \\
\text { Institute. }\end{array}$ \\
\hline $7^{\text {th }}$ & $07 / 26 / 2007$ & $\begin{array}{l}\text { 6. Inform about the activities } \\
\text { of the three working groups } \\
\text { formed under the CTPCC } \\
\text { that dealt with the following } \\
\text { issues: preliminary draft law } \\
\text { on conflict of interests; draft } \\
\text { law on access to information } \\
\text { and improvement for the } \\
\text { control of federal resources } \\
\text { transferred to States and } \\
\text { Municipalities. }\end{array}$ & $\begin{array}{l}\text { Minister Jorge Hage (CGU), Secretary } \\
\text { of the Council, Internal Control of } \\
\text { Civil House, Internal Control of Min. } \\
\text { Finance, CEP, Transparency Brazil, } \\
\text { CNBB, Attorney of the Republic (MPF), } \\
\text { Ethos Institute, General Confederation of } \\
\text { Workers (CGT). }\end{array}$ \\
\hline $8^{\text {th }}$ & 08/28/2007 & $\begin{array}{l}\text { 4. Inform about the Bill } \\
\text { that deals with Access to } \\
\text { Information }\end{array}$ & $\begin{array}{l}\text { Minister Jorge Hage (CGU), Secretary } \\
\text { of the Council, Internal Control of } \\
\text { Civil House, MRE, Internal Control of } \\
\text { Min. Finance, CEP, Transparency Brazil, } \\
\text { Ethos Institute, General Confederation } \\
\text { of Workers (CGT), Federal Secretary of } \\
\text { Internal Control (CGU), Legal Advisory } \\
\text { of CGU. }\end{array}$ \\
\hline $10^{\text {th }}$ & $03 / 25 / 2009$ & $\begin{array}{l}\text { 3. Presentation of the Bill of } \\
\text { Access to Information. }\end{array}$ & $\begin{array}{l}\text { Minister of CGU, Council, Civil House, } \\
\text { AGU, TCU, MJ, MPF, Min. Finance, CEP, } \\
\text { MRE, MPOG, Transparency Brazil, Ethos } \\
\text { Institute, OAB, ABONG, CNBB, Conf. } \\
\text { National Trade Organization. }\end{array}$ \\
\hline
\end{tabular}

Self-elaboration. Source: Minutes of the CTPCC / CGU Meeting.

Therefore, verified the phase of debates held within the Executive Branch, with social representativeness, the Civil House sent the project to National Congress, where it passed through the Chamber of Deputies (in addition to the existing bills) and, later, through the Senate. Upon resuming his journey in the Chamber of Deputies, such a project had been received and joined to the others, as a project by no. $5228 / 2009$.

Then, in an act of the Presidency of the Chamber of Deputies, a Special Commission was created to discuss the matter. In the work of this Commission, therefore, in September 2009, requests were made for a public hearing. It is known that such a mechanism is an important channel for the participation of various actors (social or state), to contribute to the work and favor the legislative improvement, as well as the work of the rapporteur. Thus, the Rapporteur (then Deputy Mendes Ribeiro Filho) presented several requests for the presence of: Minister of Justice, Representatives of the Brazilian Bar Association (OAB), Association of Brazilian Magistrates (AMB), Association of Federal Judges (AJUFE), National Association of Public Prosecutors (ANPR).

In the end, a favorable opinion on the bill was drafted, which served as a basis to elucidate the representatives of these bodies who attended. At this moment, therefore, one of the initial procedural questions in this study is relevant: within 
the scope of the National Congress: a) were there public hearings? b) if so, which entities or institutions participated?

Using these data, we can answer them by presenting the following table: there was a public hearing in the Chamber of Deputies, receiving participation from members of the State, as well as from classes of public agents (judges, magistrates, prosecutors), but also social representations (NGOs and associations of civil entities) - such as ABRAJI, ABI ANJ, Article 19, Transparency Brazil, and UnB, and international organisations, such as UNESCO.

Table 4 - Entities and bodies that contributed to a public hearing at the Chamber of Deputies.

\begin{tabular}{|l|l|}
\hline Data & Institution \\
\hline $09 / 16 / 2009$ & ANPR - National Association of Public Prosecutors \\
CONAMP - National Association of Members of the Public Ministry \\
AMB - Brazilian Magistrates Association
\end{tabular}

Self-elaboration. Source: Chamber of Deputies' website; Opinion of the Rapporteur, Dep. Mendes

Ribeiro.

The Bill, therefore, was approved in plenary (04/13/2010) and sent to the Federal Senate as Bill of the Chamber of Deputies (PLC no. 41/2010) on April 29 of the same year, 2010. In this Federal Senate, in turn, no public hearing request records were found in the documents. It is known, however, that there were attempts to restrict some provisions of the project, mainly by former presidents (such as Fernando Collor), but that they did have success. ${ }^{30}$

Finally, it was approved by the President of the Republic on November 18, 2011, coming into force on May 16, 2012. In addition, "the final draft of the Bill that was

\footnotetext{
${ }^{30}$ Karina Furtado Rodrigues, "The politics of Brazil's access to information policies: history and coalitions", Journal of Public Administration, v. 54, no. 1 (2020): 142-161, https://www.researchgate. net/profile/Karina_Rodrigues/publication/339825904_The_politics_of_Brazil's_access_to_ information_policies_history_and_coalitions/links/5e775d32299bf1892cff7320/The-politics-ofBrazils-access-to-information-policies-history-and-coalitions.pdf.
} 
approved by the Chamber of Deputies is clearly based on the proposition that was forwarded by the Executive Branch to the Congress". ${ }^{31}$

This analysis, therefore, proposed to verify: to what extent it happened and how the social participation in the process of LAI was. Thus, it appears that there was some degree of social participation, through social representative entities and professional classes (there are no records of the possibility of individual participation by citizens over the internet, for example).

We noticed that there was a strong State presence and a government effort, and of public entities in the debate and discussion of the project, envisioning an effort by the government itself to open this channel and regulate this form of social participation (through passive transparency), still within the scope of the Executive Branch. Social participation, however, has not been ruled out, being present through representative entities and even though there has been no public consultation on the Chamber of Deputies' website (as has been done today with new technologies and incentive programs for receiving contributions from the Civil Society).

Whether in the debate to formulate project no. 5228 (in the CTPCC/CGU) or in the Chamber of Deputies, NGOs that work with the theme of transparency had the possibility to contribute: Article 19, Transparency Brazil, Ethos Institute, in addition to the academy. Professional-class entities that would be affected were also called (also, both in the CTPCC and in the Chamber of Deputies), especially those linked to journalism: ABI, ABRAJI and ANJ. Thus, it was intended to analyse only the entities that contributed to this legislation.

The next topic deals with the Legislative Process of the LGPD and its amendment by MP 869/2018.

\subsection{Legislative process of LGPD: before and after Rights in Network Coalition}

To regulate data protection and privacy in Brazil, Law no. 13,709, of August 14, 2018, was approved and was planned to take effect 24 months after its publication (February 2020). However, Chapter XI that dealt with the National Data Protection Authority (ANPD) was vetoed by the President of the Republic as it was considered to breach the rules on legislative initiative. Later, Provisional Measure no. 869, of 2018 was issued to amend the Law and deal with the issue of creating ANPD, responsible for ensuring the effectiveness of the standard and its applicability. Provisional Measure no. 869 recently approved by Congress. The Provisional Measure also changed the term of the LGPD to August 2020. The approved Law originated from Bill no. 5,276, of 2016 and was part of a long legislative process.

On May 11, of 2016, after more than five years of debates, the Personal Data Protection Bill was sent by the Executive Branch to the National Congress, being received in the Chamber of Deputies as Bill no. 5,276, of 2016. Having gone through two public consultations (in the years 2010 and 2015) that obtained more than 2000 contributions from Academia, Civil Society, companies, and the public sector. ${ }^{32}$

The Bill was formed by joining Application no. 4,934, of 2016 on July 14, 2016, to Bill no. $4060,{ }^{33}$ of 2012, already pending in the Chamber of Deputies because they

\footnotetext{
${ }^{31}$ Cintra, "Lei de acesso à informação no Brasil: sua implementação e seus desafios", 99.

${ }^{32}$ L. S. Mendes and D. Doneda, "Marco jurídico para a cidadania digital: uma análise do Projeto de Lei 5.276/2016”, Revista de Direito Civil Contemporâneo, v. 9 (2016): 36.

${ }_{33}$ Brasil, Câmara dos Deputados, PL4060/2012, Tratado de dados pessoais, https://www2.camara. leg.br/atividade-legislativa/comissoes/comissoes-temporarias/especiais/55a-legislatura/pl-4060-12-
} 
are related matters. Bill no. 330, of 2013 of the Senate, proceeding together with Bills no. 131 and 181, of 2014.

Within the scope of Bill no. 4,060, of 2012, there were two public hearings in 2015, twelve in 2016, five in 2017 and two in 2018 and other conversations to deepen the debate and discuss aspects of the General Data Protection Law.

Methodologically, the search engine on the Chamber of Deputies website is used as a data source to verify the course of the Bill (Bill 4060, of 2012 attached to Bill 5276, of 2016) and possible participatory interventions by Civil Society throughout that legislative process. In this sense, it is intended to observe the holding of public hearings during this process and map the performance of entities representing the Civil Society. ${ }^{34}$

On May 6, 2015, a Public Hearing was requested, within the scope of the Commission for Science and Technology, Communication and Informatics, the following associations, were called: Brazilian Association of Advertising Agencies (ABAP), Brazilian Association Direct Marketing (ABEMD) and the Brazilian Association of Radio and Television Companies (ABERT). On September 23, 2015, the 2nd Public Hearing was requested and the National Consumer Secretary Ministry of Justice (Senacon/MJ), the Brazilian Association of Radio and Television Broadcasters (Abert), the Brasiliense Institute of Public Law (IDP) participated, and Professor Pablo Ortellado - Professor at the University of São Paulo (USP). None of them represent Civil Society.

In Public Hearing no. 2, of 2016, requested on November 17, 2016, Mr. Danilo Doneda (Professor at UERJ) was called; Mr. Ronaldo Lemos (Professor at UERJ); Mrs. Beatriz Barbosa (Intervozes - Coletivo Brasil de Comunicação Social); Mr. Bruno Bioni (Internet Steering Committee); Mr. Marco Carvalho (Internet entrepreneur); a representative from IDEC (Brazilian Institute for Consumer Protection); and a representative from CTS (FGV's Technology and Society Center). The presence of two groups of Civil Society is noted: Intervozes and IDEC, both belonging to the then newly formed Rights in Network Coalition. On November 22, of 2016, Public Hearing no. 3, of 2016 was required, the IDEC was called again. Hearings 4 to $12 \mathrm{had}$ no representatives of Civil Society.

In 2017, in turn, a Public Hearing was called, on April 3, 2017, through Presentation of Application no. 13, of 2017, with the presence of Fabricio Solagna from the Barão de Itararé Study Center and the National Forum for the Democratization of Communication (FNDC), representing Civil Society. Hearings 14 to 16 had no representatives of Civil Society. Hearing 17 counted with the presence of Marília Monteiro, lawyer, a specialist in Internet and Telecommunications, and expressly entitled on the Chamber's website as a member of the Rights in Network Coalition.

After all this process, the current Bill was transformed into Bill no. 53, of 2018 for processing in the Senate. Before the approval, there was a public hearing in the Senate to debate the Economic Affairs Committee, on June 26, 2018. With 23 participants, most of them from research institutes such as ITS Rio, universities such as UnB and UERJ partners of Rights in Network Coalition, and associations such as Brasscom and ABERT, which sign letters with the Coalition. More specifically

tratamento-e-protecao-de-dados-pessoais.

34 A. Espiñera et al., "O consentimento na proteção de dados pessoais: análise do PL 4060/2012 e sua conjuntura legislativa”, Revista dos Estudantes de Direito da UnB (RED/UNB), no. 14 (2018): 50-266. 
from Civil Society institutions that make up the Coalition directly, three of them: Bia Barbosa (Coordinator of Intervozes and Rights in Network Coalition), Igor Rodrigues Britto [Consultant of the Brazilian Institute of Consumer Protection (IDEC)], and Henrique Lian [Institutional Relations and Consumers Association Media (PROTESTE)]. Within the scope of Provisional Measure no. 869, of 2018 ${ }^{35}$, 4 public hearings took place between September 09, 2019 and April 17, 2019. In each of the hearings, there was a representative of the Coalition.

There is a growing participation of Civil Society, between 2015 and 2016 when there were 12 public hearings, only two representatives of this sector. In 2017, 2 participations are maintained in a universe of less than seven audiences (from no.13 to no.19). This participation increased considerably from 2018 onwards, when all hearings within the scope of Bill no. 53, of 2018 and Provisional Measure no. 869, of 2018 had the participation of Civil Society entities.

In the next section, the manifestations of the Rights in Network Coalition are analysed as a record of their participation in the topic of data protection and its Regulatory Authority, in order to understand the interests conveyed by these groups, and the extent to which the changes in the performance of Civil Society depending on the legislative and political moment of the propositions.

\subsection{The Growth of Rights in Network Coalition and the changes in Civil Society's role}

The Rights in Network Coalition is made up of about 38 Civil Society organisations (institutes, collectives, NGOs, think tanks), activists and academics and its aim is to defend the free and open Internet in Brazil. Formed in July 2016, it seeks to raise awareness about the right to Internet access, privacy, and freedom of expression in a broad way. The collective works on different fronts through its organisations horizontally and collaboratively.

As a complement to the analysis of Civil Society entities' performance in the LAI and LGPD legislative processes, eleven public notes, letters, and documents of Rights in Network Coalition on the performance of the LGPD theme are analysed. It should be noted that most of them are signed jointly with other entities representing actors from the Civil Society, the Academy, the Private Sector, and often even the Public Sector, promoting the multisectoral model that is defended in the Internet Governance. The materials are available on their website ${ }^{36}$ and are as follows:

1. Your Data Is You;

2. Open Letter of Support to Bill no. 5276, of May 19, 2016;

3. Note Rights in Network Coalition on Senate Bill no. 303, of 2013, May 29, 2018;

4. Document for the approval of the General Law on Protection of Personal Data, July 13, 2018;

5. Letter in defense of the Personal Data Protection Authority, of June 13, 2018;

6. Temer: Sanction the Data Protection Law without changes! Do not attack this conquest of the Brazilian people!, of July 31, 2018;

\footnotetext{
${ }^{35}$ Brasil, Congresso Nacional, MP no. 869, de 27 de dezembro de 2018, http:/ /www.planalto.gov.br/ ccivil_03/_ato2015-2018/2018/Mpv/mpv869.htm.

${ }^{36}$ See the website: https:// direitosnarede.org.br/.
} 
7. Public note on the maintenance of the National Personal Data Protection Authority, dated October 24, 2018;

8. Document for the immediate creation of the Personal Data Protection Authority, from December 6, 2018;

9. A new commitment to democracy and personal data protection required, from May 2019;

10. The Brazilian State needs to respect the commitment made with the personal data protection, of March 2020;

11. Note from the Rights in Network Coalition on Provisional Measure no. 954, of April 2020.

In Document 1 is the first manifestation of the Coalition in a campaign format entitled "Your Data is You" started in 2016, to make the population and parliamentarians aware of the importance of protecting personal data as protection of intimacy and privacy itself. "A Personal Data Protection Act is necessary so that we are not so vulnerable concerning companies and governments that make decisions that are increasingly guided by this data and, sometimes, know us better than ourselves". Within this campaign, several links are directed to other documents of institutions that make up the Coalition, and in addition to these, also the Open Letter of Support to Bill no. 5276, of 2016 (document 2 above).

The document 3 reinforces the document 2 and presents reasons to consider Bills no. 4060, of 2012 and 5276, of 2016 with fewer shortcomings than Bill no. 330, of 2013, pointing out 8 problematic points in the Bill Report.

Document 4, on the other hand, expresses support for the rapid appreciation and approval, on the part of the Federal Senate, to be then transformed into the Bill of Law of the Chamber of Deputies no. 53 of 2018. We use the argument that any previous debate in the Chamber of Deputies served to legitimise the Bill. " $A$ clear and principled data protection law, which balances the individual's central position with the economic dynamism of a creative and innovation-inclined country, such as Brazil, is essential to catalyze competitiveness".

Documents 5 and 6 were released before the presidential veto and for that reason, the risks of a possible veto are presented, demonstrating how the proposed model was satisfactory and balanced, consistent with international standards.

Document 7 was released after the veto. Document 8 concerns the need for the immediate creation and promotion of supervisory authority's independence.

In all four documents dealing with the ANPD (documents 5 to 8), "the creation of a functionally independent Personal Data Protection Authority for Brazil (...) that there is no subordination of the regulatory body to the administration is defended direct or indirect public. We also advise that a multisectoral council be created, composed of members from the public and private sectors, the third sector and academia to advise and monitor the activities of the regulatory body". "The creation of the Authority with these characteristics is essential to consolidate an institutional structure in the country, capable of providing legal certainty for the treatment of data in the country, giving effect to the rights guaranteed in the LGPD and enabling Brazil to participate in the free international flow of data".

The Charter (document 9) is addressed to the Mixed Commission of Provisional Measure no. 869, of 2018 and reinforces the need to not go back on the topic of data protection, guaranteeing an independent ANPD. This statement is summarised: "We understand that the construction of public policies must be done in a participatory manner, giving voice to different sectors [...] [preserving the] National Council for the Protection of Personal Data and Privacy, as a way of maintaining the debate with the population." 
Document 10 was published during the COVID-19 pandemic, given the delay in the entering into force of the LGPD. With the arrival of the pandemic in Brazil, the debate on data protection in the country started to turn to postponement of its entry into force so that companies had more time to adapt to the data protection mechanisms required by the new Law. As well as that whether the creation of the National Data Protection Agency was at an opportune moment since the government's focus would be the health crisis. Several bills were proposed in Congress, among them Bill no. 1,027, of 2020 with a new postponement for the LGPD to become effective in February 2022; until Provisional Measure no. 954/2020 confirmed the extension for the LGPD to be effective as of May 2021. It is important to note that this MP also provided data from users of telecommunications companies to the Brazilian Institute of Geography and Statistics ("IBGE"). However, in Direction Action of Unconstitutionality (ADI) n. 6,387 / DF proposed by the Federal Council of the OAB, the majority of the Federal Supreme Court decided to suspend the effectiveness of this measure.

Document 11 shows the consequences of operator data sharing for Government to research in the context of the COVID-19 pandemic. These would be mass collection of non-anonymised data from citizens without specific consent from their holders to companies. There is no guarantee that the use of the data would be punctual for the exclusive purpose established in the Provisional Measure, nor would there be any elimination of the data collected after this context has passed. ADI 6387 represents the result of the advocacy movement around this theme.

It is about data protection as a democratic assumption and participation in the construction of public policies and decision-making in the legislature as legitimising this process. This legitimacy is also reinforced by the culture of transparency and access to information, reflected in the LAI process.

\section{Conclusion}

It can be seen, therefore, from the analysis of the legislative process of the Access to Information Law, that there was social participation, strongly marked by governmental actors or Civil Society actors with a recognised representative dimension (CUT, Universities, Article 19, Transparency Brazil, CNBB, among others). Even though the initial Bill of 2003 was authored by a federal deputy, there was a project of the Executive Branch (2009) joined, and this one, in its elaboration, went through criticisms and suggestions from entities representing Civil Society (as well as representatives of government bodies) within the scope of the CTPCC.

In this same Bill, the participation of society in the scope of the National Congress, in turn, took place in public hearings in the Chamber of Deputies, also with representatives of social entities, NGOs, and representations of professional classes that relate to the theme. However, it is important to note that, when it comes to comparison with the participation of the LGPD Bill, this one obtained a more articulated participation in a network format. ${ }^{37}$ This means that the traditional format of representation has been replaced by a format closer to that of the lobby. These changes can be an important subject of a research agenda, disrupting participatory channels, for example, in their respective contexts. LAI obtained a more institutionalised participation within the scope of the CTPCC (entities of the

${ }^{37}$ M. Castells, Ruptura: A crise da democracia liberal. 
society that participated, at the time as members of the board), which may point out a difference in comparison with the LGPD due to the greater involvement, also of entities of the society, but also with more contributions from companies and individuals through the participatory channels then existing.

The legislative process of the LGPD despite proceeding since 2012, with the Federal Executive's Bill in 2016, gained greater notoriety and strength in the debate, giving space to the participation process with consultations and public hearings, with the performance of Civil Society entities.

Although the organisation in a Coalition of these Civil Society lobbying institutions took place in 2016, active participation in public hearings increasingly intensified in public hearings since 2018, as can be seen through the analysis carried out above, which does not diminish the work done by these institutions behind the scenes of the process. The formation of the Coalition, therefore, seems to fulfill its role of catalysing the efforts of isolated entities in a group, in order to increase not only in quantity, but in quality, the participation of Civil Society in this lobbying process, with the sum of efforts and the convergence of interests.

In both forms, it is important to emphasize the participatory channels, interests involved and knowledge of the possible effects of these Bills as a kind of strengthening of these practices in society.

The fact is that both transparency or access to information, and protection of personal data are intended for society - which somehow had a participation in the reality of each context. In both cases, such legislation moves to improve its control over the State, especially about how transparent it is in relation to public data, and the handling of data from so many citizens. 